\title{
TRITERPENOIDS FROM THE AFRICAN TREE Phyllanthus polyanthus
}

Vuyelwa J Ndlebe ${ }^{\mathrm{a}, \mathrm{b}}$, Neil R Crouch ${ }^{\mathrm{b}, \mathrm{c}}$ and Dulcie A Mulholland ${ }^{\mathrm{a}, \mathrm{b} *}$.

${ }^{a}$ Natural Products Research Group, Division of Chemistry, Faculty of Health and Medical Sciences, University of Surrey, Guildford, GU2 7XH, United Kingdom.

${ }^{\mathrm{b}}$ School of Chemistry, University of KwaZulu-Natal, P/Bag X54001, Durban, 4000, South Africa.

${ }^{\mathrm{c}}$ Ethnobotany Unit, South African National Biodiversity Institute, PO Box 52099, Berea Rd, 4007, Durban, South Africa.

* Corresponding Author. Address: Division of Chemistry, Faculty of Health and Medical Sciences, University of Surrey, Guildford, GU2 7XH, United Kingdom. E-mail address: d.mulholland@surrey.ac.uk

\begin{abstract}
The stem bark of Phyllanthus polyanthus (Phyllanthaceae) has yielded phyllanthol, phyllanthone, $(20 S)$-3 $\beta$-acetoxy24-methylenedammaran-20-ol, $\delta$-amyrin acetate and lupenone and the leaves yielded (20S)-3 $\alpha$-acetoxy-24-methylenedammaran-20-ol. NMR data for phyllanthol provided in the literature have been revised.
\end{abstract}

\section{Keywords}

Phyllanthus polyanthus; Phyllanthaceae; Dammarane, Ursane; Phyllanthol (13,27-cycloursan-

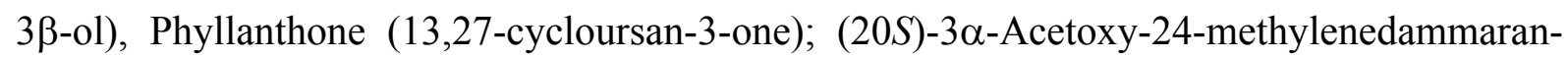
20-ol; (20S)-3 $\beta$-Acetoxy-24-methylenedammaran-20-ol; $\delta$-Amyrin acetate; Lupenone

\section{Introduction}

Phyllanthus polyanthus Pax (syn. P. cedrelifolius I.Verd.; P. delpyanus Hutch.) is a small (3-9 m) deciduous tree of coastal forests in East and southern Africa (Radcliffe-Smith, 1996). In South Africa this rarely encountered tree is known as the Forest Potato-bush; under the synonym $P$. delpyanus decocotions of the roots are employed by the Digo of Kenya in the treatment of sexually transmitted diseases (Beentje, 1994). The phytochemistry of this plant has not been investigated previously.

\section{Results and Discussion}


The hexane extract of the stem bark yielded phyllanthol, 1, phyllanthone, 2, and $\delta$-amyrin acetate, 3, and the dichloromethane extract yielded (20S)-3 $\beta$-acetoxy-24methylenedammaran-20-ol, 4, and lupenone. The combined hexane, dichloromethane and ethyl acetate extracts of the leaves yielded (20S)-3 $\alpha$-acetoxy-24-methylenedammaran-20-ol, 5.

Phyllanthol, 1, was first isolated in 1951 by Alberman and Kipping from the root bark of Phyllanthus engleri Pax. Following preparation of the acetate, benzoate and $p$-nitrobenzoate derivatives they deduced it was an alcohol of high melting point (233-234 $)$ which contained no double bonds. Using elemental analysis, they determined the molar mass as $426 \mathrm{~g}^{\mathrm{mol}}{ }^{-1}$, from which they deduced a molecular formula of $\mathrm{C}_{30} \mathrm{H}_{50} \mathrm{O}$. From these results they concluded that phyllanthol was a triterpenoid, probably related to $\psi$-taraxasterol (Alberman and Kipping, 1951). In 1953, Barton and de Mayo confirmed that no double bonds were present and from the molecular formula deduced the presence of six rings. They were able to convert phyllanthol into $\alpha$-amyrin by refluxing with $\mathrm{HCl}$ in acetic acid and accordingly interpreted phyllanthol to possess a cyclopropane ring with one apex of the cyclopropane ring terminating at $\mathrm{C}-12$ or $\mathrm{C}-13$. There were seven possible structures which could be narrowed down to a compound with a C-12,13, 27-cyclopropane ring. This was based on infra-red peaks at $3042-3052 \mathrm{~cm}^{-1}$ which are characteristic of the $\mathrm{C}-\mathrm{H}$ stretching frequency of a methylene group within a cyclopropane ring (Barton and de Mayo, 1953; Barton et al., 1954). Sengupta and Mukhopadhyay (1966) subsequently isolated phyllanthol, which they identified by comparison against an authentic sample from Phyllanthus acidus Skeels. The next report of this compound was from Phyllanthus sellowianus Muell. Arg., by Hnatyszyn and Ferraro (1985). These authors reported ${ }^{1} \mathrm{H}$ NMR and IR data, and later MS and UV data (Hnatyszyn et al., 1996) in support of their structural determination. However, in the present investigation, ${ }^{1} \mathrm{H}$ NMR data did not agree with that reported in the literature, and a complete assignment of the ${ }^{1} \mathrm{H}$ and ${ }^{13} \mathrm{C}$ NMR data was undertaken.

The ${ }^{1} \mathrm{H}$ NMR spectrum showed a proton resonance at $\delta 3.18(\mathrm{dd}, J=5.75, J=10.91 \mathrm{~Hz})$ and the corresponding ${ }^{13} \mathrm{C}$ NMR resonance occurred at $\delta$ 79.3. This resonance showed correlations in the HMBC spectrum with the $3 \mathrm{H}-23(\delta 0.96)$ and the $3 \mathrm{H}-24(\delta 0.77)$ methyl group proton resonances and the H-5 methine proton resonance $\left(\begin{array}{ll}\delta & 0.72\end{array}\right)$. The coupling constants for H-3 established that it was in an axial $(\alpha)$ configuration and hence the hydroxyl 
group was in the equatorial $(\beta)$ configuration. The COSY spectrum showed coupling between the H-3 resonance and the superimposed H-2 methylene proton resonances ( $\delta 1.57)$, which, in turn, were seen to be coupled with the $\mathrm{H}-1$ methylene proton resonances $(\delta 0.89, \delta 1.54)$. The corresponding C-1 carbon resonance ( $\delta$ 38.7) showed correlations in the HMBC spectrum with the $\mathrm{H}-9$ methine proton resonance $(\delta 0.75)$ and the $3 \mathrm{H}-25$ methyl group proton resonance ( $\delta$ 0.86). The H-9 methine resonance showed coupling in the COSY spectrum with the superimposed H-11 proton resonances ( $\delta 1.27)$, which, in turn, were seen to be coupled with the two $\mathrm{H}-12$ methylene proton resonances $(\delta 1.77$ and $\delta 1.85)$. The corresponding $\mathrm{C}-12$ carbon resonance $(\delta 35.4)$ showed correlations in the HMBC spectrum with the H-18 methine proton resonance at $\delta 0.99$ and the $2 \mathrm{H}-27$ cyclopropyl ring proton resonances at $\delta 0.00(\mathrm{~d}, J=$ $5.55 \mathrm{~Hz})$ and $\delta 0.66(\mathrm{~d}, J=5.55 \mathrm{~Hz})$. The $\mathrm{H}-27$ methylene proton resonances were seen to correlate in the HMBC spectrum with the previously assigned C-9, and C-12 resonances, and the C-8 ( $\delta 37.2), \mathrm{C}-14(\delta 32.4)$ and the C-15 ( $\delta 21.5)$ carbon resonance. The COSY spectrum showed coupling between the H-15 proton resonances $(\delta 1.42, \delta 1.82)$ and the two $\mathrm{H}-16$ proton resonances $(\delta 1.32, \delta 0.73)$.

The HMBC spectrum showed correlations between the C-16 carbon resonance $(\delta 27.5)$ and the $3 \mathrm{H}-28$ methyl group proton resonance $(\delta 0.89)$ and with the previously assigned $\mathrm{H}-18$ methine proton resonance. The COSY spectrum showed coupling between the $\mathrm{H}-18$ and $\mathrm{H}-$ $19(\delta$ 0.85) methine proton resonance, which, in turn, was seen to be coupled with the $3 \mathrm{H}-29$ $(0.93, \mathrm{~d}, \mathrm{~J}=6.00 \mathrm{~Hz})$ and the $\mathrm{H}-20$ methine proton resonance at $(\delta 0.96)$. The $\mathrm{H}-20$ methine resonance was seen to be coupled with the $3 \mathrm{H}-30$ methyl group proton resonance $(\delta 0.87, \mathrm{~d}$, $\mathrm{J}=5.60 \mathrm{~Hz})$ and the two $\mathrm{H}-21$ resonances $(\delta 0.98, \delta 1.30)$, which were further coupled with the $\mathrm{H}-22$ proton resonances $(\delta 1.24, \delta 1.32)$.

The NOESY spectrum showed correlations between the 3H-23 methyl group proton resonance and the H-5 methine resonance, which, in turn, was seen to be coupled with the H9 methine proton resonance. The $\mathrm{H}-27 \mathrm{~B}$ resonance was seen to correlate with the $3 \mathrm{H}-30$ methyl group proton resonance and with $\mathrm{H}-22 \alpha$ resonance in the NOESY spectrum. Further correlations were seen in the NOESY spectrum between the $3 \mathrm{H}-24$ and $3 \mathrm{H}-25$ methyl group proton resonances, which, in turn, showed correlation with the $3 \mathrm{H}-26$ methyl group resonance. The H-18 methine proton resonance and the 3H-28 methyl group proton resonance were seen to correlate in the NOESY spectrum. The structure of compound $\mathbf{1}$ was 
confirmed as 13, 27-cycloursan-3 $\beta$-ol or phyllanthol. Phyllanthol was acetylated to give phyllanthol acetate (1a).

Phyllanthone, 2, gave a molecular ion peak at $\mathrm{m} / \mathrm{z}$ 424.3707, which corresponded to the molecular formula of $\mathrm{C}_{30} \mathrm{H}_{48} \mathrm{O}$. The FTIR spectrum showed a ketonic carbonyl absorption band at $1708 \mathrm{~cm}^{-1}$ and the ${ }^{13} \mathrm{C}$ NMR spectrum showed the C-3 carbonyl resonance at $\delta 218.2$ which showed correlations in the HMBC spectrum with $3 \mathrm{H}-23$ and $3 \mathrm{H}-24(\delta 1.07$ and $\delta 1.03)$ methyl group proton resonances, confirming the position of the ketone group at C-3. Phyllanthone, 13, 27-cycloursan-3-one, has not been isolated previously from a natural source but has been synthesised (Barton and de Mayo, 1953). NMR data for phyllanthone is reported in Table 1.

From the literature only two other derivatives of this rare class have been isolated from the aerial roots of Ficus microcarpa L.f. (Moraceae), namely $3 \beta$-acetoxy-15 $\alpha$-hydroxy-13, 27-

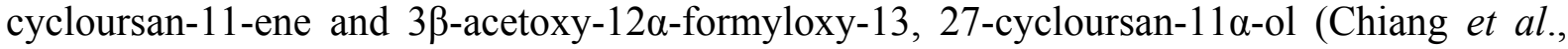
2001).

In the biosysnthesis of ursane-type compounds such as $\alpha$-amyrin, the oleanyl cation undergoes a Wagner-Meerwein, 1,2-methyl shift to produce the taraxasteryl cation, which then undergoes four Wagner-Meerwein 1,2-hydride shifts to produce $\alpha$-amyrin (Dewick, 2002). In the biosynthesis of phyllanthol, it is proposed that the 1,2-methyl shift is followed by three 1,2-hydride shifts, followed by the loss of one of the methyl group protons and bond formation between $\mathrm{C}-27$ and $\mathrm{C}-13$, to form the cyclopropyl ring.

$\delta$-Amyrin acetate, $\mathbf{3}$, and lupenone were also isolated from the stem bark and structures were confirmed by comparing NMR data against literature values (Misra et al., 1984; Carpenter et al., 1980).

The TOF-MS ES ${ }^{+}$spectrum of compound 4, (20S)-3 $\beta$-acetoxy-24-methylenedammaran-20-ol, showed a $[\mathrm{M}+\mathrm{H}]^{+}$ion peak at $\mathrm{m} / z 501.4303$ which corresponded to a molecular formula of $\mathrm{C}_{33} \mathrm{H}_{56} \mathrm{O}_{3}$ for the compound. The low resolution mass spectrum showed fragment ions at [M$15]^{+}\left(\right.$loss of $\left.\mathrm{CH}_{3}\right),[\mathrm{M}-18]^{+}$(loss of $\left.\mathrm{H}_{2} \mathrm{O}\right)$ and $[\mathrm{M}-60]^{+}$(loss of $\left.\mathrm{CH}_{3} \mathrm{COOH}\right)$. The FTIR 
spectrum showed the carbonyl stretch of an acetate group at $1726 \mathrm{~cm}^{-1}$, a hydroxyl stretch at $3298 \mathrm{~cm}^{-1}$ and $\mathrm{CH}$ stretches at 2923 and $2858 \mathrm{~cm}^{-1}$.

The presence of an acetate group was confirmed by a three proton resonance seen at $\delta 2.04$ in the ${ }^{1} \mathrm{H}$ NMR spectrum. Subtracting two carbons for the acetate group from the thirty-three carbons shown in the mass spectrum left a thirty-one carbon molecule, suggesting a methylated triterpenoid. The presence of the eight methyl groups and a terminal methylene group in the molecule supported this.

A resonance at $\delta 4.45(\mathrm{dd}, J=10.65, J=5.75 \mathrm{~Hz})$ in the ${ }^{1} \mathrm{H}$ NMR spectrum was assigned as $\mathrm{H}-3$ and corresponded to the C-3 resonance $\delta 81.1$ in the ${ }^{13} \mathrm{C}$ NMR spectrum. The coupling constants indicated that H-3 was in the $\alpha$-orientation. The acetate group was placed at C-3 $\beta$ due to a correlation seen in the HMBC spectrum between the acetate group carbonyl carbon resonance at $\delta 171.2$ and the $\mathrm{H}-3$ resonance. The $\mathrm{C}-3$ carbon resonance showed correlations in the HMBC spectrum with the $3 \mathrm{H}-28$ and $3 \mathrm{H}-29$ methyl group proton resonances $(\delta 0.82, \delta$ $0.85)$, the H-5 methine proton resonance $(\delta 0.83)$ and with the two $\mathrm{H}-1$ methylene proton resonances $(\delta 1.66, \delta 1.02)$, which showed coupling with the superimposed H-2 methylene proton resonances at $\delta 1.61$ in the COSY spectrum.

The H-1 proton resonances showed correlations with the carbon resonances ascribed to the C19 methyl group carbon $(\delta 15.7)$, the C-9 methine carbon $(\delta 50.8)$, the C-5 methine carbon $(\delta$ 56.2 ), the C-8 fully substituted carbon ( $\delta$ 40.6) and the C-3 carbon resonance, previously assigned, in the HMBC spectrum. The C-9 carbon resonance showed correlations in the HMBC spectrum with the $3 \mathrm{H}-30(\delta 0.94)$ and $3 \mathrm{H}-19(\delta 0.84)$ methyl group proton resonances and the two methylene proton resonances at $\delta 1.72$ and $\delta 1.49$, which were ascribed to $2 \mathrm{H}-12$. The two H-12 resonances showed coupling with the two H-11 methylene proton resonances at $\delta 1.47$ and $\delta 1.22$ in the COSY spectrum and also with the $\mathrm{H}-13$ methine proton resonance at $\delta$ 1.63. The C-13 resonance ( $\delta 42.5$ showed a correlation with the $3 \mathrm{H}-18$ resonance $(\delta 0.85)$. Correlations were observed in the COSY spectrum between the H-13 methine resonance and the H-17 methine proton resonance $(\delta 1.76)$, which was seen to be further coupled with the two H-16 methylene proton resonances $(\delta 1.81, \delta 1.27)$, which, in turn were seen to be coupled with the two H-15 methylene proton resonances ( $\delta 1.45$ and $\delta 1.07$ ), which showed no further coupling. 
The H-17 resonance showed correlations in the HMBC spectrum with a methyl group carbon resonance ascribed to C-21 ( $\delta 25.6)$, the C-22 methylene carbon resonance ( $\delta 39.7)$, and a fully substituted carbon resonance which could be ascribed to C-20 ( $\delta 75.5)$. The two H-22 proton resonances $(\delta 1.59)$ showed coupling in the COSY spectrum with the $2 \mathrm{H}-23(\delta 2.09)$ proton resonances. The corresponding C-23 carbon resonance at $\delta 28.6$ showed correlations with the two terminal methylene proton resonances $(2 \mathrm{H}-24 \mathrm{a}, \delta 4.72, \delta 4.66)$ and with the $\mathrm{H}-$ 25 methine proton resonance at $\delta 2.27$ in the HMBC spectrum. The H-25 methine resonance showed coupling with the $3 \mathrm{H}-27$ and $3 \mathrm{H}-26$ methyl group proton resonances $(\delta 1.04, \mathrm{~d}, J=$ $6.82 \mathrm{~Hz})$.

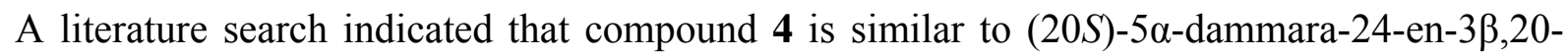
diol isolated from Panax L. (Araliaceae) (gingseng) (Akasawa et al., 1977) and two related dammaranes, trans-securinegin [(20S)-20-hydroxy-24-methylenedammarane-3a-yl (2E)-3-(4hydroxyphenyl)-2-propenoate $]$ and cis-securinegin [(20S)-20-hydroxy-24methylenedammarane-3 $\alpha$-yl $\quad$ (2Z)-3-(4-hydroxyphenyl)-2-propenoate] isolated from Securinega melanthesoides (F.Muell.) H.K. Airy Shaw (Eurphorbiaceae) ( Schutz et al., 1998).

Asakawa et al. (1977) and Schutz et al. (1998) have investigated the effects of the stereochemistry at $\mathrm{C}-20$ on the ${ }^{13} \mathrm{C}$ shifts of the $\mathrm{C}-21$ and $\mathrm{C}-22$ resonances. Asakawa et al. (1977) compared the shifts of C-21 and C-22 for C-20 epimers of dammaranes with either 3 $\beta$ hydroxy or 3-keto groups. Schutz et al. (1998) used Asakawa's conclusion to determine the stereochemistry at C-20 as $S$ for cis and trans-securinegin. By comparing values of compound 4 against those of Asakawa et al. (1977) and Schutz et al. (1998) it was concluded that the $20 S$ stereochemistry is present in compound 4.

The NOESY spectrum confirmed the dammarane stereochemistry. A correlation was seen in the NOESY spectrum between the H-5 resonance and the H-9, $3 \mathrm{H}-28$ and the $3 \mathrm{H}-18$ proton resonances. The 3H-29 resonance showed a correlation with the $3 \mathrm{H}-19$ resonance which showed a correlation with the $3 \mathrm{H}-30$ resonance, which, in turn, showed a correlation with the $\mathrm{H}-13$ resonance establishing all these to be in the $\beta$-orientation. As expected, no correlations were seen between the $\mathrm{H}-13$ and the $3 \mathrm{H}-18$ resonances, neither between the $\mathrm{H}-13$ and the $\mathrm{H}-$ 17 resonances. Compound 4, (20S)-3ß-acetoxy-24-methylenedammaran-20-ol has not been 
reported previously. Methylation at C-24 of the sidechain is fairly common and seen in triterpenoids such as 24-methylenecycloartenol, gramisterol, ergosterol and campesterol (Dewick, 2002).

The TOF ES ${ }^{+}$mass spectrum of compound 5, (20S)-3 $\alpha$-acetoxy-24-methylenedammaran-20ol, gave a $[\mathrm{M}+\mathrm{H}]^{+}$peak at $m / z 501.4308$, which corresponded to a molecular formula for the compound of $\mathrm{C}_{33} \mathrm{H}_{56} \mathrm{O}_{3}$. The FTIR spectrum showed a carbonyl stretch at $1728 \mathrm{~cm}^{-1}, \mathrm{CH}$ stretches 2933 and $2851 \mathrm{~cm}^{-1}$ and a hydroxyl stretch at $3415 \mathrm{~cm}^{-1}$. Compound 5 was found to differ from compound 4 in the stereochemistry at C-3. The H-3 resonance was seen to occur as a triplet ( $\mathrm{t}, J=2.75 \mathrm{~Hz}$ ) at $\delta 4.61$. The coupling constant showed that $\mathrm{H}-3$ was in an equatorial $(\beta)$ position, hence the acetate was in an axial $(\alpha)$ position. Compound 5 , $(20 S)-3 \alpha-$ acetoxy-24-methylenedammaran-20-ol, has not been reported previously.

\section{Experimental}

\subsection{General experimental procedures}

NMR spectra were recorded at room temperature on a $500 \mathrm{MHz}$ Bruker AVANCE NMR spectrometer. Chemical shifts $(\delta)$ are expressed in ppm relative to tetramethylsilane (TMS) as internal standard and coupling constants are given in Hz. IR spectra were recorded on a Perkin - Elmer System 2000 FT-IR spectrometer, using NaCl windows with dichloromethane as solvent against an air background. EI/FI MS were recorded on a Waters GCT TOF mass spectrometer using a temperature programmed solids probe or a Bruker Micro TOF mass spectrometer with an Agilent 1100 HPLC to introduce the samples. Optical rotations were determined in chloroform at room temperature using a Jasco P-1020 polarimeter.

\subsection{Plant material}

Stem bark and leaves of Phyllanthus polyanthus Pax (Phyllanthaceae) were collected by Professor N. Crouch of the South African National Biodiversity Institute (SANBI) from a tree cultivated in Kloof, South Africa. A fruiting voucher specimen was retained at the KwaZuluNatal Herbarium (N. Crouch 1012, NH).

\subsection{Extraction and isolation of compounds}

The milled stem bark $(754 \mathrm{~g})$ and leaves $(350 \mathrm{~g})$ of $P$. polyanthus were extracted using a Soxhlet apparatus for 24 hours sequentially with hexane, dichloromethane, ethyl acetate and 
then methanol. The solvent was removed under vacuum to yield the following extracts: from the stem bark: hexane $(18.2 \mathrm{~g})$, dichloromethane $(7.75 \mathrm{~g})$, ethyl acetate $(1.65 \mathrm{~g})$, methanol $(88.4 \mathrm{~g})$, and from the leaves: hexane $(17.2 \mathrm{~g})$, dichloromethane $(2.60 \mathrm{~g})$, ethyl acetate $(5.65$ g), methanol (114.7 g). Thin layer chromatography indicated that the hexane, dichloromethane and ethyl acetate extracts of the leaves were similar and they were combined. Both methanol extracts appeared to contain only sugars, so were not investigated further. Extracts were separated using gravity column silica gel column chromatography (Merck 9385). Extracts were loaded onto a $5 \mathrm{~cm}$ diameter column and eluted with step gradient solvent systems using hexane, EtOAc and $\mathrm{CH}_{2} \mathrm{Cl}_{2}$, collecting $40 \mathrm{~cm}^{3}$ fractions. Final purification was undertaken using Pasteur pipettes packed with silica gel.

The hexane extract of the stem bark yielded phyllanthone (2) (fr. 30-40, $40 \% \mathrm{CH}_{2} \mathrm{Cl}_{2} / 60 \%$ hexane), ( $\delta$-amyrin acetate (3) (fr. 44-52, 40\% $\mathrm{CH}_{2} \mathrm{Cl}_{2} / 60 \%$ hexane), lupenone (fr. 66-71, $50 \% \mathrm{CH}_{2} \mathrm{Cl}_{2} / 50 \%$ hexane) and phyllanthol (1) (fr. 80-98, $80 \% \mathrm{CH}_{2} \mathrm{Cl}_{2} / 20 \%$ hexane). The dichloromethane extract of the stem yielded (20S)-3 $\beta$-acetoxy-24-methylenedammaran -20-ol (4) (fr. 170-180, 100\% $\mathrm{CH}_{2} \mathrm{Cl}_{2}$ ) and the ethyl acetate extract yielded the same compound. The combined hexane and dichloromethane extracts of the leaves yielded (20S)-3 $\alpha$-acetoxy24-methylenedammaran-20-ol (5) (fr. 190-209, 100\% $\mathrm{CH}_{2} \mathrm{Cl}_{2}$ ).

Phyllanthol (13, 27-cycloursan-3 $\beta$-ol) (1): white crystalline powder (15 mg); EIMS: $\mathrm{M}^{+} \mathrm{m} / \mathrm{z}$ 426.3849 (calcd. for $\left.\mathrm{C}_{30} \mathrm{H}_{50} \mathrm{O}, 426.3862\right)$; IR: $v_{\max }(\mathrm{NaCl}) \mathrm{cm}^{-1}: 3235 \mathrm{~cm}^{-1}(\mathrm{O}-\mathrm{H}$ stretch), $2924 \mathrm{~cm}^{-1}$ (CH stretch), 1449 (cyclopropyl ring stretch). $[\alpha]_{\mathrm{D}}{ }^{24}:+49^{\circ}\left(\mathrm{c}=4.16 \times 10^{-3}, \mathrm{CHCl}_{3}\right)$; Mp: 238-239 $;{ }^{1} \mathrm{H}$ and ${ }^{13} \mathrm{C}$ NMR data are presented in Table 1.

Phyllanthol acetate (3 $\beta$-acetoxy-13, 27-cycloursane) (1a) : needle-like crystals from $\mathrm{MeOH}$; EIMS: $\mathrm{M}^{+}$at $m / z 468\left(\mathrm{C}_{32} \mathrm{H}_{52} \mathrm{O}_{2}\right), 453,408\left[\mathrm{M}^{+}-\mathrm{CH}_{3} \mathrm{COOH}\right], 393,281,207$; IR: $v_{\max }(\mathrm{NaCl})$ $\mathrm{cm}^{-1}: 1731(\mathrm{C}=\mathrm{O}), 2926,2849(\mathrm{C}-\mathrm{H}$ stretch $) ;[\alpha]_{\mathrm{D}}{ }^{24}=+43.3^{\circ}\left(\mathrm{c}=5.76 \times 10^{-3}, \mathrm{CHCl}_{3}\right) ; \mathrm{Mp}: 197-$ $199{ }^{\circ} ;{ }^{1} \mathrm{H}$ and ${ }^{13} \mathrm{C}$ NMR data are presented in Table 1.)

Phyllanthone (13, 27-cycloursan-3-one) (2): needle-like crystals (MeOH) (10.6 mg); EIMS: $\mathrm{M}^{+}$at $\mathrm{m} / z 424.3707$ (calculated for $\left.\mathrm{C}_{30} \mathrm{H}_{48} \mathrm{O}, 424.3705\right)$; IR: $v_{\max }(\mathrm{NaCl}) \mathrm{cm}^{-1}: 1708(\mathrm{C}=\mathrm{O}$ stretch), 2920, $2858(\mathrm{C}-\mathrm{H}$ stretch $) ;[\alpha]_{\mathrm{D}}{ }^{24}=+55.8^{\circ}\left(\mathrm{c}=6.2 \times 10^{-3}\right) ; \mathrm{Mp}: 157-159^{\circ},{ }^{1} \mathrm{H}$ and ${ }^{13} \mathrm{C}$ NMR data are presented in Table 1 


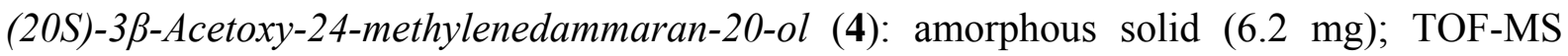
$\mathrm{ES}^{+}:[\mathrm{M}+\mathrm{H}]^{+}$at $\mathrm{m} / z$ 501.4303, (calculated for $\mathrm{C}_{33} \mathrm{H}_{57} \mathrm{O}_{3}$ 501.4308); IR: $v_{\max }(\mathrm{NaCl}) \mathrm{cm}^{-1}$ : 3298 (O-H stretching), $1726 \mathrm{~cm}^{-1}$ (C=O stretch), 2923, $2858 \mathrm{~cm}^{-1}$ (C-H stretch); $[\alpha]_{\mathrm{D}}{ }^{24}=+7.6$ $\left(\mathrm{c}=4.06 \times 10^{-3}, \mathrm{CHCl}_{3}\right)$; Mp: 201-203 $;{ }^{1} \mathrm{H}$ and ${ }^{13} \mathrm{C}$ NMR data are presented in Table $2 .$.

(20S)-3a-Acetoxy-24-methylenedammaran-20-ol (5): amorphous solid (7.7 mg); TOF-MS $\mathrm{ES}^{+}:[\mathrm{M}+\mathrm{H}]^{+}$ion peak at $m / z$ 501.4308, (calculated for $\mathrm{C}_{33} \mathrm{H}_{57} \mathrm{O}_{3}$ 501.4308); IR: $v_{\max }(\mathrm{NaCl})$ $\mathrm{cm}^{-1}: 1726(\mathrm{C}=\mathrm{O}$ stretch$), 2933,2851(\mathrm{CH}$ stretch$) ;[\alpha]_{\mathrm{D}}{ }^{24}=+9.3^{\circ}\left(\mathrm{c}=6.98 \times 10^{-3}, \mathrm{CHCl}_{3}\right)$; Mp: $189-191^{\circ} ;{ }^{1} \mathrm{H}$ and ${ }^{13} \mathrm{C}$ NMR data are presented in Table 2.

\section{Acknowledgements}

V Ndlebe would like to thank the NRF (South Africa) and the Collins Educational Trust for for postgraduate bursaries. We thank Mr Dilip Jagjivan (University of KwaZulu-Natal) and Mr Jim Bloxridge (University of Surrey) for assistance with obtaining NMR spectra, and Mr Bret Parel (University of KwaZulu-Natal) and Mr Colin Sparrow (University of Oxford) for MS analyses. The Mary Gunn Library (SANBI) staff kindly facilitated access to literature. This research was funded by the NRF.

\section{References}

Asakawa, J., Kasai, R., Yamasaki, K. and Tanaka, O., 1977. ${ }^{13} \mathrm{C}$ NMR study of Gingseng sapogenins and their related dammarane type triterpenoids. Tetrahedron, 33, 1935-1939. Alberman, K.B. and Kipping, F.B., 1951. Phyllanthol. A new alcohol from the root bark of Phyllanthus engleri. Journal of the Chemical Society, 2296-2297.

Barton, D. H. R. and de Mayo, P., 1953. Triterpenoids. Part XIII. Phyllanthol, the first hexacarbocyclic triterpenoid. Journal of the Chemical Society, 2178-2181.

Barton, D. H. R., Page, J. E. and Warnhoff, E. W., 1954. Triterpenoids. Part XIII. The constitution of phyllanthol and cycloartenol. Journal of the Chemical Society, 2715-2719.

Beentje, H., 1994. Kenya Trees, Shrubs and Lianes. National Museums of Kenya, Nairobi, Kenya.

Carpenter, R. C., Sotheeswaran, S., Sultanbawa, M. U. S. and Ternai, B., $1980 .{ }^{13}$ C NMR studies of some lupane and taraxerane triterpenes. Organic Magnetic Resonance, 14, 462465. 
Chiang, Y. M., Su, J. K., Liu, Y. H. and Kuo, Y. H., 2001. New cyclopropyl triterpenoids from the aerial roots of Ficus microcarpa. Chemical Pharmaceutical Bulletin, 49, 581-583.

Dewick, P. M., 2002. Medicinal Natural Products, A Biosynthetic Approach, $2^{\text {nd }}$ edition. John Wiley \& Sons, Chichester, England.

Hnatyszyn, O. and Ferraro, G., 1985. Phyllanthol from Phyllanthus sellowianus. Planta Medica, 467.

Hnatyszyn, O., Ferraro, G. E. and Coussio, J. D., 1996. Phenolic and triterpenic compounds from Phyllanthus sellowianus. Acta Farmaceutica Bonaerense, 15, 21-28.

Misra, T. N., Singh, R. S., Upadhyay, J. and Srivastava, R., 1984. Chemical constituents of Vernonia cinerea, Part I. Isolation and spectral studies of triterpenes. Journal of Natural Products, 47, 368-372.

Radcliffe-Smith, A., 1996. Euphorbiaceae. Flora zambesiaca 9(4), 36-85.

Schutz, B., Orjala, J., Sticher, O. and Topul, R., 1998. Dammarane triterpenes from the leaves of Securinega melanthesoides. Journal of Natural Products, 61, 96-98.

Sengupta, P. and Mukhopadhyay, J., 1966. Terpenoids and related compounds. VII. Triterpenoids of Phyllanthus acidus. Phytochemistry, 5, 531-534. 

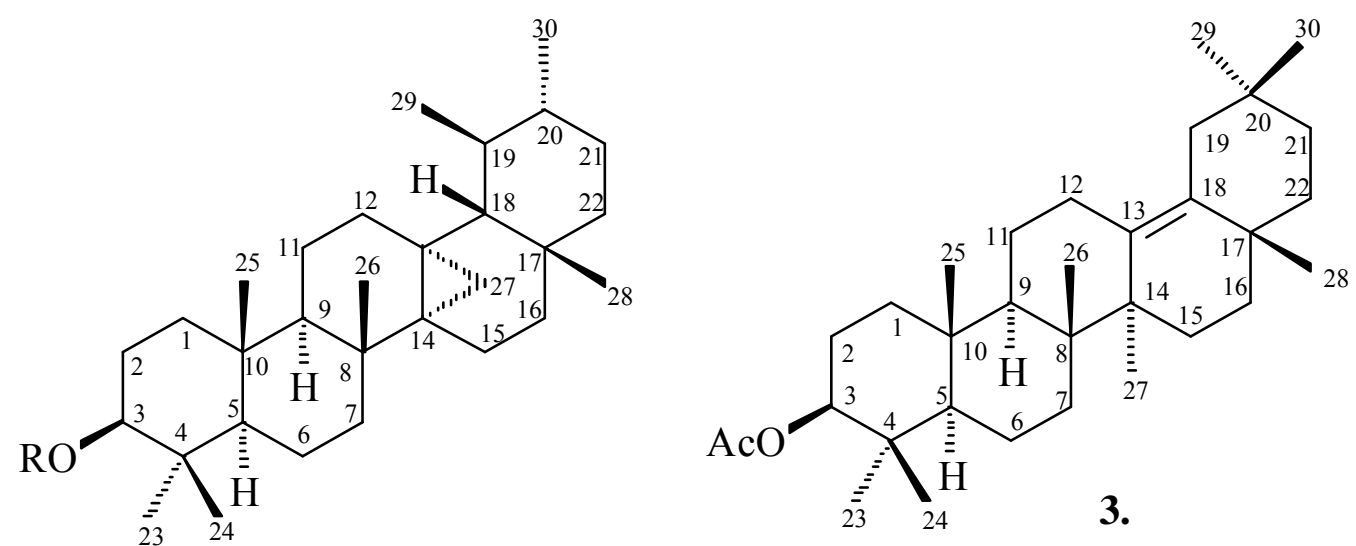

1. $\mathrm{R}=\beta-\mathrm{OH}$

1a. $\mathrm{R}=\beta-\mathrm{OAc}$

2. $\mathrm{R}==\mathrm{O}$

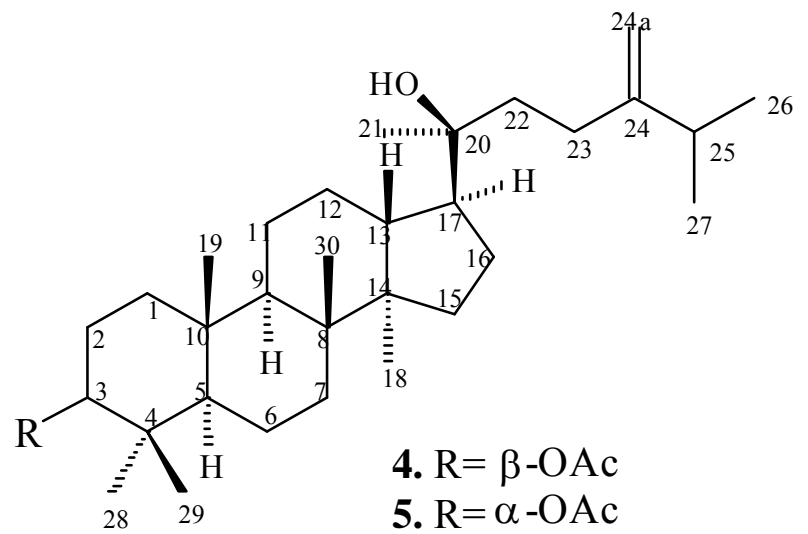

Figure 1. Compounds isolated from Phyllanthus polyanthus. 
Table 1. NMR Data for Phyllanthol, 1, Phyllanthol acetate, 1a, and Phyllanthone, 2. $\left(\mathrm{CDCl}_{3}, 500 \mathrm{MHz}\right)$

\begin{tabular}{|c|c|c|c|c|c|c|}
\hline $\mathrm{C}$ & $\mathbf{1}^{1} \mathrm{H}$ & $1^{13} \mathrm{C}$ & $1 \mathrm{a}^{1} \mathrm{H}$ & $1 a^{13} \mathrm{C}$ & $2{ }^{1} \mathrm{H}$ & $2^{13} \mathrm{C}$ \\
\hline $1 \alpha$ & $0.89(1 \mathrm{H}, \mathrm{m})$ & \multirow{2}{*}{$38.7\left(\mathrm{CH}_{2}\right)$} & $0.96(1 \mathrm{H}, \mathrm{m})$ & \multirow[t]{2}{*}{$38.2\left(\mathrm{CH}_{2}\right)$} & $1.78(1 \mathrm{H}, \mathrm{m})$ & \multirow[t]{2}{*}{$39.5\left(\mathrm{CH}_{2}\right)$} \\
\hline $1 \beta$ & $1.54(1 \mathrm{H}, \mathrm{m})$ & & $1.55(1 \mathrm{H}, \mathrm{m})$ & & $1.36(1 \mathrm{H}, \mathrm{m})$ & \\
\hline $2 \alpha$ & $1.57(1 \mathrm{H}, \mathrm{m})$ & \multirow{2}{*}{$27.5\left(\mathrm{CH}_{2}\right)$} & $1.60(1 \mathrm{H}, \mathrm{m})$ & \multirow{2}{*}{$23.7\left(\mathrm{CH}_{2}\right)$} & $2.48(1 \mathrm{H}, \mathrm{m})$ & \multirow[t]{2}{*}{$34.3\left(\mathrm{CH}_{2}\right)$} \\
\hline $2 \beta$ & $1.57(1 \mathrm{H}, \mathrm{m})$ & & $1.60(1 \mathrm{H}, \mathrm{m})$ & & $2.38(1 \mathrm{H}, \mathrm{m})$ & \\
\hline 3 & $\begin{array}{l}3.18(J=5.75 \\
J=10.91 \mathrm{~Hz})\end{array}$ & $79.3(\mathrm{CH})$ & $\begin{array}{l}4.49(1 \mathrm{H}, \\
J=5.70,11.0 \\
\mathrm{~Hz})\end{array}$ & $81.2(\mathrm{CH})$ & - & $218.2(\mathrm{C})$ \\
\hline 4 & - & $39.1(\mathrm{C})$ & - & $40.0(\mathrm{C})$ & - & $47.7(\mathrm{C})$ \\
\hline 5 & $0.72(1 \mathrm{H}, \mathrm{m})$ & $55.9(\mathrm{CH})$ & $0.83(1 \mathrm{H}, \mathrm{m})$ & $56.0(\mathrm{CH})$ & $1.35(1 \mathrm{H}, \mathrm{m})$ & $55.5(\mathrm{CH})$ \\
\hline $6 \alpha$ & $1.54(1 \mathrm{H}, \mathrm{m})$ & \multirow[t]{2}{*}{$18.3\left(\mathrm{CH}_{2}\right)$} & $1.52(1 \mathrm{H}, \mathrm{m})$ & \multirow{2}{*}{$18.2\left(\mathrm{CH}_{2}\right)$} & $1.77(1 \mathrm{H}, \mathrm{m})$ & \multirow{2}{*}{$37.9\left(\mathrm{CH}_{2}\right)$} \\
\hline $6 \beta$ & $1.37(1 \mathrm{H}, \mathrm{m})$ & & $1.37(1 \mathrm{H}, \mathrm{m})$ & & $1.25(1 \mathrm{H}, \mathrm{m})$ & \\
\hline $7 \alpha$ & $1.72(1 \mathrm{H}, \mathrm{m})$ & \multirow[t]{2}{*}{$38.7\left(\mathrm{CH}_{2}\right)$} & $1.72(1 \mathrm{H}, \mathrm{m})$ & \multirow[t]{2}{*}{$38.6\left(\mathrm{CH}_{2}\right)$} & $1.31(1 \mathrm{H}, \mathrm{m})$ & $18.1\left(\mathrm{CH}_{2}\right)$ \\
\hline $7 \beta$ & $1.21(1 \mathrm{H}, \mathrm{m})$ & & $1.20(1 \mathrm{H}, \mathrm{m})$ & & $1.31(1 \mathrm{H}, \mathrm{m})$ & \\
\hline 8 & - & $37.2(\mathrm{C})$ & - & $37.2(\mathrm{C})$ & - & $37.0(\mathrm{C})$ \\
\hline 9 & $0.75(1 \mathrm{H}, \mathrm{m})$ & $54.2(\mathrm{CH})$ & $0.75(1 \mathrm{H}, \mathrm{m})$ & $54.2(\mathrm{CH})$ & $0.78(1 \mathrm{H}, \mathrm{m})$ & $54.6(\mathrm{CH})$ \\
\hline 10 & - & $37.5(\mathrm{C})$ & - & $37.4(\mathrm{C})$ & - & $37.2(\mathrm{C})$ \\
\hline $11 \alpha$ & $1.27(1 \mathrm{H}, \mathrm{m})$ & \multirow[t]{2}{*}{$17.8\left(\mathrm{CH}_{2}\right)$} & $1.27(1 \mathrm{H}, \mathrm{m})$ & \multirow[t]{2}{*}{$17.8\left(\mathrm{CH}_{2}\right)$} & $1.47(1 \mathrm{H}, \mathrm{m})$ & \multirow[t]{2}{*}{$19.6\left(\mathrm{CH}_{2}\right)$} \\
\hline $11 \beta$ & $1.27(1 \mathrm{H}, \mathrm{m})$ & & $1.27(1 \mathrm{H}, \mathrm{m})$ & & $1.47(1 \mathrm{H}, \mathrm{m})$ & \\
\hline $12 \alpha$ & $1.77(1 \mathrm{H}, \mathrm{m})$ & \multirow[t]{2}{*}{$35.4\left(\mathrm{CH}_{2}\right)$} & $1.77(1 \mathrm{H}, \mathrm{m})$ & \multirow[t]{2}{*}{$35.3\left(\mathrm{CH}_{2}\right)$} & $1.87(1 \mathrm{H}, \mathrm{m})$ & \multirow[t]{2}{*}{$35.8\left(\mathrm{CH}_{2}\right)$} \\
\hline $12 \beta$ & $1.85(1 \mathrm{H}, \mathrm{m})$ & & $1.86(1 \mathrm{H}, \mathrm{m})$ & & $1.80(1 \mathrm{H}, \mathrm{m})$ & \\
\hline 13 & - & $26.6(\mathrm{C})$ & - & $26.2(\mathrm{C})$ & - & $19.9(\mathrm{C})$ \\
\hline 14 & - & $32.4(\mathrm{C})$ & - & $32.4(\mathrm{C})$ & - & $32.7(\mathrm{C})$ \\
\hline $15 \alpha$ & $1.42(1 \mathrm{H}, \mathrm{m})$ & \multirow[t]{2}{*}{$21.5\left(\mathrm{CH}_{2}\right)$} & $1.42(1 \mathrm{H}, \mathrm{m})$ & $21.5\left(\mathrm{CH}_{2}\right)$ & $1.84(1 \mathrm{H}, \mathrm{m})$ & \multirow[t]{2}{*}{$21.5\left(\mathrm{CH}_{2}\right)$} \\
\hline $15 \beta$ & $1.82(1 \mathrm{H}, \mathrm{m})$ & & $1.81(1 \mathrm{H}, \mathrm{m})$ & & $1.47(1 \mathrm{H}, \mathrm{m})$ & \\
\hline $16 \alpha$ & $1.32(1 \mathrm{H}, \mathrm{m})$ & \multirow[t]{2}{*}{$27.5\left(\mathrm{CH}_{2}\right)$} & $1.32(1 \mathrm{H}, \mathrm{m})$ & \multirow[t]{2}{*}{$27.5\left(\mathrm{CH}_{2}\right)$} & $1.34(1 \mathrm{H}, \mathrm{m})$ & \multirow[t]{2}{*}{$27.4\left(\mathrm{CH}_{2}\right)$} \\
\hline $16 \beta$ & $0.73(1 \mathrm{H}, \mathrm{m})$ & & $0.74(1 \mathrm{H}, \mathrm{m})$ & & $0.75(1 \mathrm{H}, \mathrm{m})$ & \\
\hline 17 & - & $32.1(\mathrm{C})$ & - & $32.1(\mathrm{C})$ & - & $32.1(\mathrm{C})$ \\
\hline 18 & $0.99(1 \mathrm{H}, \mathrm{m})$ & $50.3(\mathrm{CH})$ & $1.01(1 \mathrm{H}, \mathrm{m})$ & $50.3(\mathrm{CH})$ & $1.08(1 \mathrm{H}, \mathrm{m})$ & $49.8(\mathrm{CH})$ \\
\hline 19 & $0.85(1 \mathrm{H}, \mathrm{m})$ & $41.0(\mathrm{CH})$ & $0.84(1 \mathrm{H}, \mathrm{m})$ & $40.9(\mathrm{CH})$ & $0.86(1 \mathrm{H}, \mathrm{m})$ & $41.0(\mathrm{CH})$ \\
\hline 20 & $0.96(1 \mathrm{H}, \mathrm{m})$ & $38.7(\mathrm{CH})$ & $0.96(1 \mathrm{H}, \mathrm{m})$ & $38.6(\mathrm{CH})$ & $0.98(1 \mathrm{H}, \mathrm{m})$ & $38.6(\mathrm{CH})$ \\
\hline $21 \alpha$ & $0.98(1 \mathrm{H}, \mathrm{m})$ & \multirow[t]{2}{*}{$31.3\left(\mathrm{CH}_{2}\right)$} & $0.98(1 \mathrm{H}, \mathrm{m})$ & \multirow[t]{2}{*}{$31.3\left(\mathrm{CH}_{2}\right)$} & $1.32(1 \mathrm{H}, \mathrm{m})$ & $31.3\left(\mathrm{CH}_{2}\right)$ \\
\hline $21 \beta$ & $1.30(1 \mathrm{H}, \mathrm{m})$ & & $1.29(1 \mathrm{H}, \mathrm{m})$ & & $0.98(1 \mathrm{H}, \mathrm{m})$ & \\
\hline $22 \alpha$ & $1.24(1 \mathrm{H}, \mathrm{m})$ & $42.3\left(\mathrm{CH}_{2}\right)$ & $1.23(1 \mathrm{H}, \mathrm{m})$ & $42.3\left(\mathrm{CH}_{2}\right)$ & $1.33(1 \mathrm{H}, \mathrm{m})$ & $42.2\left(\mathrm{CH}_{2}\right)$ \\
\hline $22 \beta$ & $1.32(1 \mathrm{H}, \mathrm{m})$ & & $1.30(1 \mathrm{H}, \mathrm{m})$ & & $1.33(1 \mathrm{H}, \mathrm{m})$ & \\
\hline 23 & $0.96(3 \mathrm{H}, \mathrm{s})$ & $28.1\left(\mathrm{CH}_{3}\right)$ & $0.84(3 \mathrm{H}, \mathrm{s})$ & $28.1\left(\mathrm{CH}_{3}\right)$ & $1.07(3 \mathrm{H}, \mathrm{s})$ & $26.7\left(\mathrm{CH}_{3}\right)$ \\
\hline 24 & $0.77(3 \mathrm{H}, \mathrm{s})$ & $15.5\left(\mathrm{CH}_{3}\right)$ & 0.84 & $16.6\left(\mathrm{CH}_{3}\right)$ & $1.03(3 \mathrm{H}, \mathrm{s})$ & $21.0\left(\mathrm{CH}_{3}\right)$ \\
\hline 25 & $0.86(3 \mathrm{H}, \mathrm{s})$ & $16.2\left(\mathrm{CH}_{3}\right)$ & 0.89 & $16.3\left(\mathrm{CH}_{3}\right)$ & $0.96(3 \mathrm{H}, \mathrm{s})$ & $15.8\left(\mathrm{CH}_{3}\right)$ \\
\hline 26 & $1.11(3 \mathrm{H}, \mathrm{s})$ & $18.2\left(\mathrm{CH}_{3}\right)$ & 1.13 & $18.2\left(\mathrm{CH}_{3}\right)$ & $1.18(3 \mathrm{H}, \mathrm{s})$ & $17.9\left(\mathrm{CH}_{3}\right)$ \\
\hline $27 \mathrm{~A}$ & $\begin{array}{l}0.66(\mathrm{~d}, J= \\
5.55 \mathrm{~Hz}\end{array}$ & $13.5\left(\mathrm{CH}_{2}\right)$ & $\begin{array}{l}0.65(1 \mathrm{H}, \mathrm{d}, J \\
=5.55 \mathrm{~Hz}\end{array}$ & $13.5\left(\mathrm{CH}_{2}\right)$ & $\begin{array}{l}0.63(1 \mathrm{H}, \mathrm{d}, J \\
=5.40 \mathrm{~Hz})\end{array}$ & $13.8\left(\mathrm{CH}_{2}\right)$ \\
\hline $27 \mathrm{~B}$ & $\begin{array}{l}0.00(\mathrm{~d}, J= \\
5.55 \mathrm{~Hz}\end{array}$ & & $\begin{array}{l}0.01(1 \mathrm{H}, \mathrm{d}, J= \\
5.55 \mathrm{~Hz}\end{array}$ & & $\begin{array}{l}0.05(1 \mathrm{H}, \mathrm{d}, J \\
=5.40 \mathrm{~Hz})\end{array}$ & \\
\hline 28 & $0.89(3 \mathrm{H}, \mathrm{s})$ & $28.4\left(\mathrm{CH}_{3}\right)$ & $0.89(3 \mathrm{H}, \mathrm{s})$ & $28.4\left(\mathrm{CH}_{3}\right)$ & $0.90(3 \mathrm{H}, \mathrm{s})$ & $28.5\left(\mathrm{CH}_{3}\right)$ \\
\hline 29 & $\begin{array}{l}0.93(1 \mathrm{H}, \mathrm{d}, J \\
=6.00 \mathrm{~Hz})\end{array}$ & $18.3\left(\mathrm{CH}_{3}\right)$ & 0.93 & 18.1 & $\begin{array}{l}0.93(1 \mathrm{H}, \mathrm{d}, J \\
=6.00 \mathrm{~Hz})\end{array}$ & $18.1\left(\mathrm{CH}_{3}\right)$ \\
\hline 30 & $\begin{array}{l}0.87(1 \mathrm{H}, \mathrm{d}, J \\
=5.60 \mathrm{~Hz})\end{array}$ & $20.9\left(\mathrm{CH}_{3}\right)$ & 0.86 & $20.9\left(\mathrm{CH}_{3}\right)$ & $\begin{array}{l}0.87(1 \mathrm{H}, \mathrm{d}, J \\
=5.60 \mathrm{~Hz})\end{array}$ & $21.2\left(\mathrm{CH}_{3}\right)$ \\
\hline 31 & $\mathrm{COCH}_{3}$ & - & - & $171.2(\mathrm{C})$ & & \\
\hline 32 & $\mathrm{COCH}_{3}$ & - & 2.05 & $21.5\left(\mathrm{CH}_{3}\right)$ & & \\
\hline
\end{tabular}


Table 2. NMR Data for compounds 3 and $4\left(\mathrm{CDCl}_{3}, 500 \mathrm{MHz}\right)$

\begin{tabular}{|c|c|c|c|c|}
\hline $\mathrm{C}$ & $3^{1} \mathbf{H}$ & $3^{13} \mathrm{C}$ & $4^{1} \mathrm{H}$ & $4^{13} \mathrm{C}$ \\
\hline $1 \alpha$ & $1.05(1 \mathrm{H}, \mathrm{m})$ & \multirow[t]{2}{*}{$38.9\left(\mathrm{CH}_{2}\right)$} & $1.17(1 \mathrm{H}, \mathrm{m})$ & \multirow[t]{2}{*}{$34.5\left(\mathrm{CH}_{2}\right)$} \\
\hline $1 \beta$ & $1.68(1 \mathrm{H}, \mathrm{m})$ & & $1.43(1 \mathrm{H}, \mathrm{m})$ & \\
\hline $2 \alpha$ & $1.62(1 \mathrm{H}, \mathrm{m})$ & \multirow[t]{2}{*}{$23.9\left(\mathrm{CH}_{2}\right)$} & $1.88(1 \mathrm{H}, \mathrm{m})$ & \multirow[t]{2}{*}{$23.1\left(\mathrm{CH}_{2}\right)$} \\
\hline $2 \beta$ & $1.62(1 \mathrm{H}, \mathrm{m})$ & & $1.57(1 \mathrm{H}, \mathrm{m})$ & \\
\hline 3 & $\begin{array}{l}4.46(\mathrm{dd}, J=10.65, \\
5.75 \mathrm{~Hz})\end{array}$ & $81.1(\mathrm{CH})$ & $\begin{array}{l}4.61(1 \mathrm{H}, \mathrm{t}, J=2.75 \\
\mathrm{Hz})\end{array}$ & $78.6\left(\mathrm{CH}_{2}\right)$ \\
\hline 4 & - & $38.1(\mathrm{C})$ & - & $37.3(\mathrm{C})$ \\
\hline 5 & $0.83(1 \mathrm{H}, \mathrm{m})$ & $56.2(\mathrm{CH})$ & $1.21(1 \mathrm{H}, \mathrm{m})$ & $50.9(\mathrm{CH})$ \\
\hline $6 \alpha$ & $152(1 \mathrm{H}, \mathrm{m})$ & \multirow[t]{2}{*}{$18.4\left(\mathrm{CH}_{2}\right)$} & $1.41(1 \mathrm{H}, \mathrm{m})^{*}$ & \multirow[t]{2}{*}{$18.2\left(\mathrm{CH}_{2}\right)$} \\
\hline $6 \beta$ & $1.44(1 \mathrm{H}, \mathrm{m})$ & & $1.41(1 \mathrm{H}, \mathrm{m})^{*}$ & \\
\hline $7 \alpha$ & $153(1 \mathrm{H}, \mathrm{m})$ & \multirow[t]{2}{*}{$35.4\left(\mathrm{CH}_{2}\right)$} & $1.58(1 \mathrm{H}, \mathrm{m})$ & \multirow[t]{2}{*}{$35.2\left(\mathrm{CH}_{2}\right)$} \\
\hline $7 \beta$ & $1.27(1 \mathrm{H}, \mathrm{m})$ & & $1.28(1 \mathrm{H}, \mathrm{m})$ & \\
\hline 8 & - & $40.6(\mathrm{C})$ & - & $40.7(\mathrm{C})$ \\
\hline 9 & $1.35(1 \mathrm{H}, \mathrm{m})$ & $50.8(\mathrm{CH})$ & $1.45(1 \mathrm{H}, \mathrm{m})$ & $50.6(\mathrm{CH})$ \\
\hline 10 & - & $37.2(\mathrm{C})$ & - & $37.4(\mathrm{C})$ \\
\hline $11 \alpha$ & $1.25(1 \mathrm{H}, \mathrm{m})$ & \multirow[t]{2}{*}{$21.8\left(\mathrm{CH}_{2}\right)$} & $1.53(1 \mathrm{H}, \mathrm{m})$ & \multirow[t]{2}{*}{$21.5\left(\mathrm{CH}_{2}\right)$} \\
\hline $11 \beta$ & $1.49(1 \mathrm{H}, \mathrm{m})$ & & $1.24(1 \mathrm{H}, \mathrm{m})$ & \\
\hline $12 \alpha$ & $1.74(1 \mathrm{H}, \mathrm{m})$ & \multirow[t]{2}{*}{$25.0\left(\mathrm{CH}_{2}\right)$} & $1.52(1 \mathrm{H}, \mathrm{m})$ & \multirow[t]{2}{*}{$24.9\left(\mathrm{CH}_{2}\right)$} \\
\hline $12 \beta$ & $1.52(1 \mathrm{H}, \mathrm{m})$ & & $1.72(1 \mathrm{H}, \mathrm{m})$ & \\
\hline 13 & $1.63(1 \mathrm{H}, \mathrm{m})$ & $42.6(\mathrm{CH})$ & 1.65 & $42.5(\mathrm{CH})$ \\
\hline 14 & - & $50.6(\mathrm{C})$ & - & $50.6(\mathrm{C})$ \\
\hline $15 \alpha$ & $1.45(1 \mathrm{H}, \mathrm{m})$ & \multirow[t]{2}{*}{$31.4\left(\mathrm{CH}_{2}\right)$} & $1.47(1 \mathrm{H}, \mathrm{m})$ & \multirow[t]{2}{*}{$31.5\left(\mathrm{CH}_{2}\right)$} \\
\hline $15 \beta$ & $1.07(1 \mathrm{H}, \mathrm{m})$ & & $1.08(1 \mathrm{H}, \mathrm{m})$ & \\
\hline $16 \alpha$ & $1.81(1 \mathrm{H}, \mathrm{m})$ & \multirow[t]{2}{*}{$27.7\left(\mathrm{CH}_{2}\right)$} & $1.81(1 \mathrm{H}, \mathrm{m})$ & \multirow[t]{2}{*}{$27.8\left(\mathrm{CH}_{2}\right)$} \\
\hline $16 \beta$ & $1.27(1 \mathrm{H}, \mathrm{m})$ & & $1.27(1 \mathrm{H}, \mathrm{m})$ & \\
\hline 17 & $1.76(1 \mathrm{H}, \mathrm{m})$ & $50.0(\mathrm{CH})$ & 1.77 & $49.9(\mathrm{CH})$ \\
\hline 18 & $0.85(3 \mathrm{H}, \mathrm{s})$ & $16.7\left(\mathrm{CH}_{3}\right)$ & $0.92(3 \mathrm{H}, \mathrm{s})$ & $16.9\left(\mathrm{CH}_{3}\right)$ \\
\hline 19 & $0.84(3 \mathrm{H}, \mathrm{s})$ & $16.5\left(\mathrm{CH}_{3}\right)$ & $0.96(3 \mathrm{H}, \mathrm{s})$ & $15.7\left(\mathrm{CH}_{3}\right)$ \\
\hline 20 & - & $75.5(\mathrm{C})$ & - & $75.6(\mathrm{C})$ \\
\hline 21 & $1.16(1 \mathrm{H}, \mathrm{m})$ & $25.6\left(\mathrm{CH}_{3}\right)$ & $1.16(3 \mathrm{H}, \mathrm{s})$ & $25.5\left(\mathrm{CH}_{3}\right)$ \\
\hline $22 \alpha$ & $1.59(1 \mathrm{H}, \mathrm{m})$ & \multirow[t]{2}{*}{$39.7\left(\mathrm{CH}_{2}\right)$} & $1.59(1 \mathrm{H}, \mathrm{m})$ & \multirow[t]{2}{*}{$39.6\left(\mathrm{CH}_{2}\right)$} \\
\hline $22 \beta$ & $1.59(1 \mathrm{H}, \mathrm{m})$ & & $1.59(1 \mathrm{H}, \mathrm{m})$ & \\
\hline $23 \alpha$ & $2.09(1 \mathrm{H}, \mathrm{m})$ & \multirow[t]{2}{*}{$28.6\left(\mathrm{CH}_{2}\right)$} & $2.09(1 \mathrm{H}, \mathrm{m})$ & \multirow[t]{2}{*}{$28.6\left(\mathrm{CH}_{2}\right)$} \\
\hline $23 \beta$ & $2.09(1 \mathrm{H}, \mathrm{m})$ & & $2.09(1 \mathrm{H}, \mathrm{m})$ & \\
\hline 24 & - & $156.7(\mathrm{C})$ & - & $156.7(\mathrm{C})$ \\
\hline $24 a$ & $4.74(1 \mathrm{H}, b r s)$ & \multirow[t]{2}{*}{$106.4\left(\mathrm{CH}_{2}\right)$} & $4.74(1 \mathrm{H}, \mathrm{brs})$ & \multirow[t]{2}{*}{$106.4\left(\mathrm{CH}_{2}\right)$} \\
\hline $24 \mathrm{a}$ & $4.66(\mathrm{~d}, J=0.95 \mathrm{~Hz})$ & & $4.68(1 \mathrm{H}, J=0.55 \mathrm{~Hz})$ & \\
\hline 25 & $\begin{array}{l}2.27(1 \mathrm{H}, \text { sept, } J= \\
6.82 \mathrm{~Hz})\end{array}$ & $34.2(\mathrm{CH})$ & $\begin{array}{l}2.24(1 \mathrm{H}, \text { sept, } J=6.82 \\
\mathrm{Hz})\end{array}$ & $34.2(\mathrm{CH})$ \\
\hline 26 & $1.04(1 \mathrm{H}, \mathrm{d}, J=6.82)$ & $22.0\left(\mathrm{CH}_{3}\right)$ & $1.03(1 \mathrm{H}, \mathrm{d}, J=6.82)$ & $22.1\left(\mathrm{CH}_{3}\right)$ \\
\hline 27 & $1.04(1 \mathrm{H}, \mathrm{d}, J=6.82)$ & $22.0\left(\mathrm{CH}_{3}\right)$ & $103(1 \mathrm{H}, \mathrm{d}, J=6.82)$ & $22.1\left(\mathrm{CH}_{3}\right)$ \\
\hline 28 & $0.82(3 \mathrm{H}, \mathrm{s})$ & $28.2\left(\mathrm{CH}_{3}\right)$ & $0.82(3 \mathrm{H}, \mathrm{s})$ & $28.1\left(\mathrm{CH}_{3}\right)$ \\
\hline 29 & $0.82(3 \mathrm{H}, \mathrm{s})$ & $16.7\left(\mathrm{CH}_{3}\right)$ & $0.86(3 \mathrm{H}, \mathrm{s})$ & $22.1\left(\mathrm{CH}_{3}\right)$ \\
\hline 30 & $0.94(3 \mathrm{H}, \mathrm{s})$ & $15.7\left(\mathrm{CH}_{3}\right)$ & $0.92(3 \mathrm{H}, \mathrm{s})$ & $16.8\left(\mathrm{CH}_{3}\right)$ \\
\hline $\mathrm{O}-\mathrm{CO}-\mathrm{CH}_{3}$ & - & $171.2(\mathrm{C})$ & - & $171.0(\mathrm{C})$ \\
\hline $\mathrm{O}-\mathrm{CO}-\mathrm{CH}_{3}$ & $2.04(3 \mathrm{H}, \mathrm{s})$ & $21.5\left(\mathrm{CH}_{3}\right)$ & $2.08(3 \mathrm{H}, \mathrm{s})$ & $21.9\left(\mathrm{CH}_{3}\right)$ \\
\hline
\end{tabular}

